\title{
Erratum to clinical presentation and imaging characteristics of clear cell sarcoma-like tumour of the gastrointestinal tract with liver metastasis: a case description
}

\author{
Editorial Office \\ Quantitative Imaging in Medicine and Surgery \\ Correspondence to: Editorial Office. Quantitative Imaging in Medicine and Surgery. Email: qims@amepc.org.
}

Submitted Nov 16, 2021. Accepted for publication Nov 19, 2021.

doi: 10.21037/qims-2021-06

View this article at: https://dx.doi.org/10.21037/qims-2021-06

Erratum to Quant Imaging Med Surg 2021;11:4690-4

The article "Clinical presentation and imaging characteristics of clear cell sarcoma-like tumour of the gastrointestinal tract with liver metastasis: a case description" [Quant Imaging Med Surg 2021;11(11):4690-4694], written by Liao et al. (1), was published with an error.

This article (1), that appeared on page 4691, unfortunately contained a mistake in Figure 1A. The position of the red arrow is wrong. The correct image of Figure 1 is presented in this erratum. This correction does not change the conclusions of the article.

The corrected version of Figure 1 is presented below.
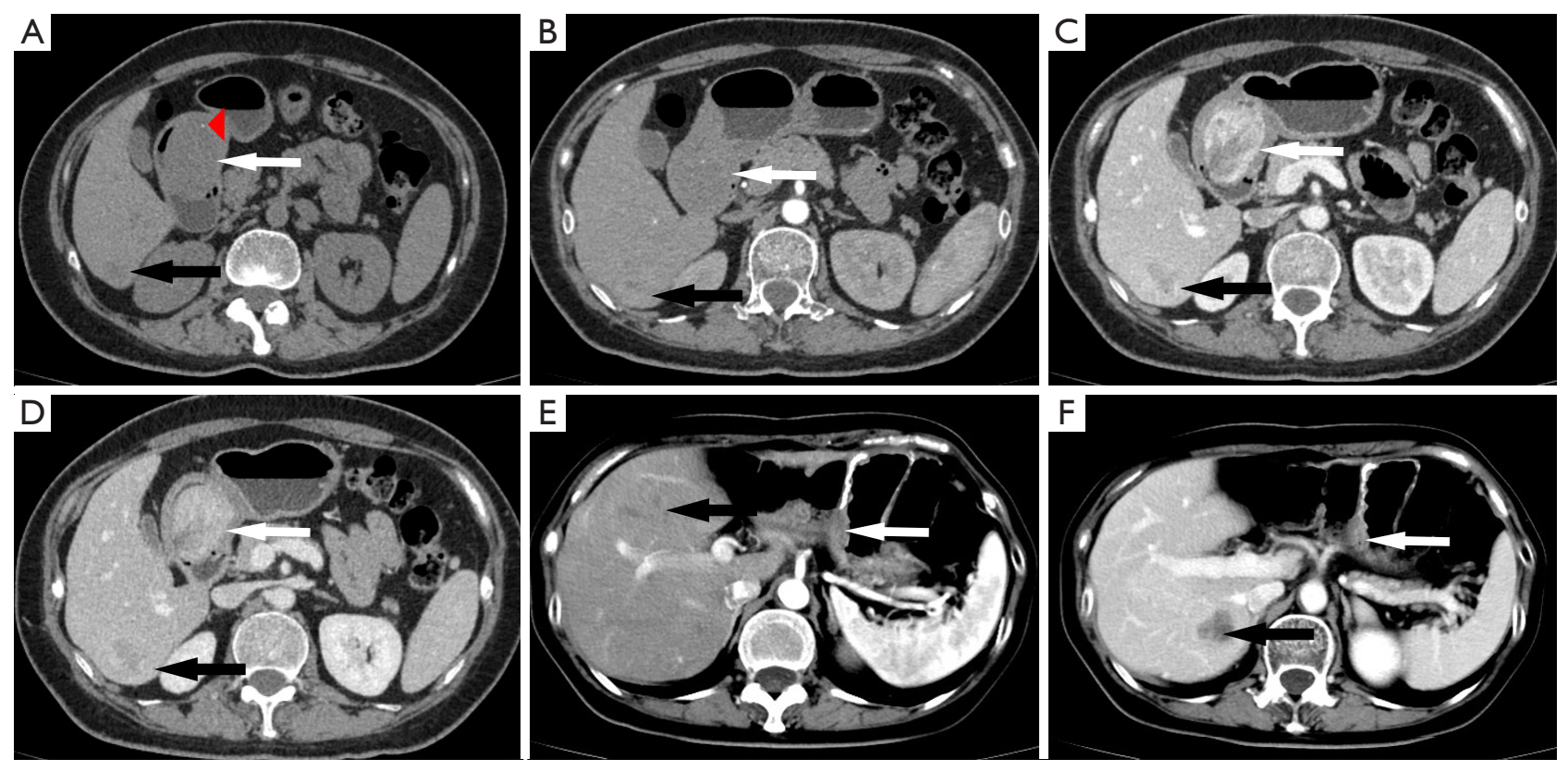
We regret the errors.

Click here to view the updated version of the article.

Open Access Statement: This is an Open Access article distributed in accordance with the Creative Commons AttributionNonCommercial-NoDerivs 4.0 International License (CC BY-NC-ND 4.0), which permits the non-commercial replication and distribution of the article with the strict proviso that no changes or edits are made and the original work is properly cited (including links to both the formal publication through the relevant DOI and the license). See: https://creativecommons.org/ licenses/by-nc-nd/4.0/.

\section{References}

1. Liao S, Wang X, Li J, Yu X. Clinical presentation and imaging characteristics of clear cell sarcoma- like tumour of the gastrointestinal tract with liver metastasis: a case description. Quant Imaging Med Surg 2021;11:4690-4.

Cite this article as: Editorial Office. Erratum to clinical presentation and imaging characteristics of clear cell sarcomalike tumour of the gastrointestinal tract with liver metastasis: a case description. Quant Imaging Med Surg 2022;12(4):26182619. doi: 10.21037/qims-2021-06 